\title{
Notícia Bibliográfica
}

\author{
Mélanges Pierre Lévêque, 1. Paris, Les Belles Lettres, \\ 1988 , LXIII $+330 \mathrm{p}$.
}

José Antônio Dabdad Trabulsi

Universidade Federal de Ouro Freto

Por ocasião do $\mathrm{XX}$ aniversário da criação por Pierre Lévêque do Centre d'Histoire Ancienne de Blesançon, os amigos, colegas e discípulos do grande helenista participam do grande projeto que representam estes "Mélanges". Só o primeiro volume, de um total de cinco previstos, conta com 25 contribuições em mais de trezentas páginas, o que mostra a amplitude da ambição do projeto. $O$. fio temático deste primeiro volume é a reflexão sobre a religião. De David Asheri a Jean-Pierre Vernant, da nossa Sílvia de Carvalho a Mario Attilio Levi e Bernard Sergent entre outros, todos, na diversidade dos seus artigos, fazem deste volume uma leitura indispensável aos que se interessam pelo assunto. Mais de trinta páginas (!) no início do livro repertoriam a bibliografia de $\mathrm{P}$. Lévêque, resultado de toda uma vida de pesquisas, da qual o leitor brasileiro infelizmente (mas como acontece com frequiência) conhece muito pouco, além da célebre Aventura Grega.

Os próximos quatro volumes versarão sobre os temas ligados à "Antropologia" e "Sociedade", segundo o plano estabelecido pelos editores, Marie-Madeleine Mactoux e Evelyne Geny. Posso adiantar que no segundo volume, a sair em breve, estão incluídos trabalhos de Pierre Briant e Yvon Garlan, Jean Pouilloux e M. Sakellariou, Pierre Vidal-Naquet e Françoise Dunand, entre muitos outros, provenientes de inúmeros países. Todas as contribuições mostram a importância deste "carrefour" que tem sido o Centro de Besançon 
nos últimos tempos, com uma média de uma dezena de livros por ano, difícil de atingir mesmo entre os grandes centros de pesquisa sobre a Antigüidade.

Gostaria de voltar a este assunto (a contribuição de Besançon à pesquisa na área) aqui mesmo, numa contribuição mais longa. Mas uma constatação salta aos olhos, desde já. Para se atingir o alto nível de pesquisa que este exemplo evidencia, muitas condições são indispensáveis (mesmo num país rico): financiamento público, constituição de bibliotecas e sua constante atualização, política ousada de publicações mas dentro de uma exigência de qualidade sempre elevada. Resta também a sensibilização de um público relativamente vasto (pelo menos o conjunto do público universitário), para que a distribuição e as vendas efetivas cubram uma parte cada vez maior dos custos de edição. Mas quem fala de edição fala de leitura; e falar em leitura e em gosto pelo saber é como pregar no deserto neste país onde a Televisão Globo e a sua mãe, a ditadura militar, levaram a cabo (em vinte anos, o tempo de vida do Centro Besançon) um projeto, bem sucedido, de infantilização e embrutecimento de toda uma nação. 